\title{
Kesiapan Adaptasi Metode Beyond Budgeting Sebagai Upaya Pembaharuan Manajemen Kinerja (Studi pada: Urban Style by Front One Hotel, Lampung, \\ Sumatera Selatan)
}

Affiliation:

Universitas Putra Bangsa, Indonesia

*Correspondence:

enikarahajeng198.stiepb@gmail.com

This Article is Avalilable in:

https://journal.umy.ac.id/index.php/jat i/article/view/12570

DOI:

https://doi.org/10.18196/jati.v4i2.125 70

Citation:

Kaharti, E. (2021). Kesiapan Adaptasi Metode Beyond Budgeting Sebagai Upaya Pembaharuan Manajemen Kinerja (Studi pada Urban Style by Front One Hotel, Lampung, Sumatera Selatan). Jati: Jurnal Akuntansi Terapan Indonesia, 4(2), 140-151.

\section{Article History}

Received:

26 Agustus 2021

Reviewed:

19 September 2021

Revised:

27 September 2021

Accepted:

01 October 2021

\section{Topic Article:}

Management Accounting

\section{Eni Kaharti*}

\section{Abstract:}

This study aimed to examine the possibility of applying the Beyond Budgeting method. The method consists of 12 principles consisting of 6 principles of adaptive management and 6 principles of flexible organizational structure. The qualitative research was conducted through a case study on the hospitality sector (Urban Style by Front One Hotel in Lampung). The research started by introducing adaptive control management, in particular the Beyond Budgeting method. Respondents in this study were the Management Team (GM and Staff) of Urban Style by Front One Hotel. Primary data was obtained by distributing questionnaires and interviews to the management team carried out via Zoom. Data analysis was through calculations by de Waal (2003) and was denoted into three colors of Green (ready), Orange (average) and Red (not ready). The results show that USBFOH has not been able to apply the Beyond Budgeting method regardless of their interest due to the moderate readiness for change (orange), while the prerequisites are not met (red) because the permit is held by a higher authority even though the change is necessary (green).

Keywords: Traditional Budgeting, Beyond Budgeting, Performance Management

\section{Abstrak:}

Penelitian ini bertujuan untuk menguji kemungkinan penerapan metode Beyond Budgeting. Metode tersebut terdiri dari 12 prinsip yang terdiri dari 6 prinsip manajemen adaptif dan 6 prinsip struktur organisasi fleksibel. Penelitian kualitatif ini dilakukan dengan melakukan studi kasus pada sebuah perusahaan di bidang perhotelan (Urban Style by Front One Hotel di Lampung). Urban Style by Front One Hotel masih menggunakan sistem penganggaran tradisional yang belum memuaskan pihak manajemen. Oleh karena itu, manajemen kontrol adaptif diperkenalkan, khususnya metode Beyond Budgeting. Responden dalam penelitian ini adalah Tim Manajemen (GM dan Staff) Urban Style by Front One Hotel. Data primer diperoleh dengan menyebarkan kuesioner dan wawancara kepada tim manajemen yang dilakukan melalui media zoom. Analisis data dilakukan melalui perhitungan yang dikenalkan oleh de Waal (2003) dan dilambangkan dengan tiga warna yaitu Hijau (siap), Oranye (sedang) dan Merah (belum siap). Hasil penelitian menunjukkan bahwa USBFOH belum dapat menerapkan metode Beyond Budgeting terlepas ketertarikan mereka yang disebabkan oleh kesiapan perubahan yang relatif sedang (oranye), namun prasyarat tidak terpenuhi (merah) karena izin dipegang oleh otoritas lebih tinggi walaupun perubahan sistem dibutuhkan (hijau).

Kata Kunci: Anggaran Tradisional, Beyond Budgeting, Manajemen Kinerja 
Kaharti

Kesiapan Adaptasi Metode Beyond Budgeting

Sebagai Upaya Pembaharuan Manajemen Kinerja

\section{PENDAHULUAN}

Anggaran digunakan sebagai alat perencanaan dan pengendalian jangka pendek yang efektif dalam organisasi, dengan karakteristik untuk mengestimasikan laba, dinyatakan dalam satuan moneter, biaya yang meliputi waktu selama satu tahun sebagai komitmen manajemen (Anthony dan Govindarajan,2011). Anggaran merupakan kegiatan mengenai apa yang diharapkan, direncanakan atau diperkirakan terjadi dalam periode tertentu pada masa yang akan datang (Brownell dan Mclnnes, 1986, dalam Suryanto dan Kurniasih ,2019).

Anggaran tradisional merupakan pendekatan yang banyak digunakan di negara berkembang dewasa ini (Suryanto dan Kurniasih, 2019). Dalam anggaran tradisonal terdapat dua ciri utama dalam pendekatan ini, yaitu cara penyusunan anggaran yang didasarkan atas pendekatan incrementalism dan struktur dan susunan anggaran yang bersifat line-item yang melekat pada pendekatan anggaran tradisional tersebut adalah cenderung sentralitis, bersifat spesifikasi, tahunan, dan menggunakan prinsip anggaran bruto (Bastian, 2010).

Adanya konsensus di kalangan bisnis Amerika bahwa proses penganggaran tradisional tidak seperti yang diharapkan (Hope dan Fraser, 2003). Ketidakpuasan terhadap anggaran sangat dirasakan di banyak perusahaan dengan tiga alasan utama yaitu penganggaran rumit dan terlalu mahal (Budgeting is cumbersome and too expensive), penganggaran tidak sesuai dengan lingkungan persaingan dan tidak lagi memenuhi kebutuhan eksekutif atau manajer operasional (Budgeting is out of kilter with the competitive environment and no longer meets the needs of either executives or operating mangers), serta "permainan angka" telah meningkat ke tingkat yang tidak dapat diterima "Gaming the numbers" has risen to an unacceptable level).

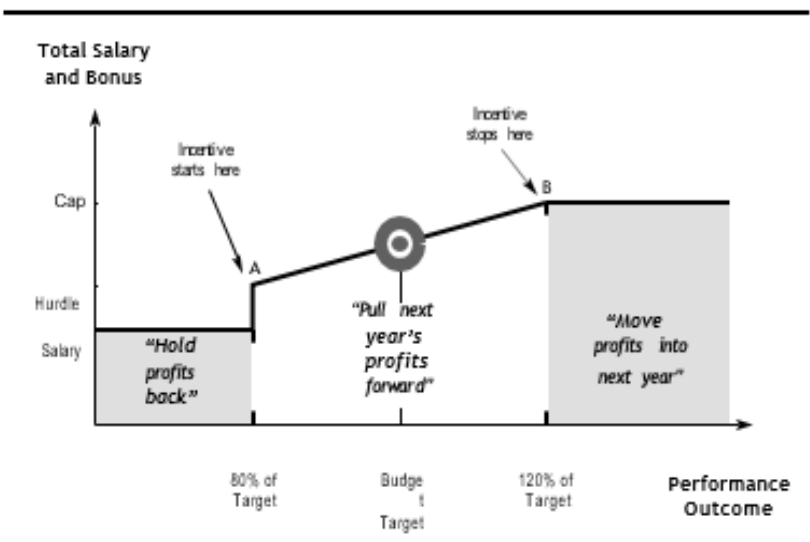

Gambar 1. Kegagalan Anggaran Tradisional Sumber: Jensen (2002)

Gambar 1 menunjukkan adanya korelasi antara insentif yang diperoleh dengan hasil kerja yang dicapai. Skema insentif berdasar pencapaian target sesuai kesepakatan yaitu pada titik 100\% Namun penghitungan pemberian bonus dimulai pada titik $80 \%$ dari target dan berakhir pada titik $120 \%$. Sebagai contoh, jika seorang manajer tidak dapat mencapai target minimum dari target yang disepakati (titik A), Titik A diketahui sebagai titik awal perhitungan bonus, maka manajer tidak mendapatkan bonus. Mungkin tahun depan diatur sebaik mungkin agar tidak meleset dari target dengan selisih jumlah yang besar.

Skema insentif seperti gambar 1 mendorong manajer untuk memaksimalkan keuntungan. Namun, untuk mencapai bonus maksimum dapat dilakukan dengan cara yang curang yaitu menetapkan pendapatan tahun depan di tahun berjalan dan menunda 


\section{Kaharti}

Kesiapan Adaptasi Metode Beyond Budgeting

Sebagai Upaya Pembaharuan Manajemen Kinerja

pengeluaran saat ini ke tahun depan, hal ini permainan yang biasa dilakukan. Semua permainan ini mungkin dianggap rasional bagi manajer, namun tidak demikian bagi pemegang saham yang lebih memilih untuk memaksimalkan kinerja setiap tahun.

Karena terdapat hubungan linier antara hasil dan penghargaan, maka pimpinan harus mengadopsi sistem pembayaran bonus-untuk-kinerja linier yang dapat menghargai hasil kinerja aktual, terlepas dari target anggaran yang disepakati (Jensen, 2002). Seorang manajer menerima bonus yang sama untuk tingkat kinerja tertentu, apakah menetapkan anggaran di bawah tingkat itu (titik A) atau di atasnya (titik B). Tujuannya adalah menghilangkan insentif untuk mempermainkan prosesnya. Sistem pembayaran bonus dengan dasar target relatif serta mengubah penghargaan individu menjadi penghargaan berbasis tim kerja (Jensen, 2002).

Dengan memahami kelemahan anggaran tradisional dan ketidakpuasan dengan system penganggaran maka perlu pengenalan metode pengendalian manajemen baru yang disebut beyong budgeting. Model Beyond Budgeting ini tujuannya tidak hanya untuk mengurangi biaya penganggaran dan menerapkan proses perencanaan yang lebih adaptif, tetapi juga untuk mengalihkan tanggung jawab atas strategi dan akuntabilitas hasil kepada tim yang lebih dekat dengan pelanggan (Player, 2003). Bagaimana organisasi-organisasi ini menangani penghargaan adalah penentu utama dari keberhasilan transformasi anggaran.

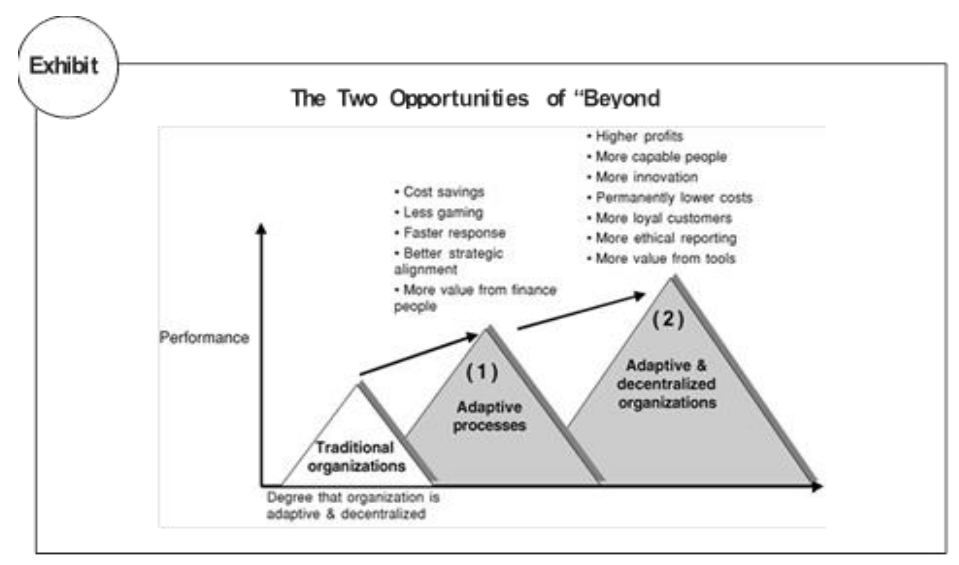

Gambar 2. Dua Peluang Beyond Budgeting Sumber: Player (2003)

Ada perusahaan lain telah mengambil pendekatan yang lebih radikal dan telah meninggalkan penganggaran sama sekali dan merombak semua langkah dalam pengendalian manajemen, termasuk menetapkan tujuan dan penghargaan, merumuskan menyusun rencana tindakan, dan mengukur serta mengendalikan kinerja. Perusahaan tersebut kemudian mengambil dua peluang penting dengan melakukan dua hal penting yaitu Proses manajemen kinerja yang lebih adaptif dan Desentralisasi radikal (Player, 2003).

Dalam proses penganggaran dibagi dengan dua siklus manajemen kinerja yaitu manager Senior mengambil pandangan strategis dan terus melihat dua sampai lima tahun ke depan (dengan tinjauan tahunan), sedangkan Manajer Menengah mengambil pandangan operasional dan melihat lima hingga delapan kuartal ke depan (dengan tinjauan kuartalan) (Jensen, 2002). Manajer fokus pada strategi jangka menengah daripada target tetap jangka pendek, dan pada indikator kinerja utama (IKU) tingkat tinggi daripada angkaangka terperinci (Player, 2003).

Dalam penelitian ini, peneliti melakukan studi kasus untuk mengetahui kemungkinan penerapan model beyond budgeting pada perusahaan yang bergerak di bidang hospitality di kota Lampung, Sumatra Selatan, yaitu Hotel Urban Style. Sebab selama ini salah satu 


\section{Kaharti}

Kesiapan Adaptasi Metode Beyond Budgeting

Sebagai Upaya Pembaharuan Manajemen Kinerja

penilaian manajemen dianggap gagal jika tidak dapat memenuhi anggaran yang telah ditetapkan.

Pencapaian anggaran yang optimal berhubungan dengan kepentingan 3 pihak utama. Yang pertama adalah karyawan, hal ini terkait dengan perolehan insentif kepada karyawan yang mendukung kesejahteraan mereka. Harapan untuk mensejahterakan karyawan yang berpengaruh terhadap semangat kerja sangat penting nilainya dengan menempatkan karyawan sebagai asset perusahaan. Pihak kedua adalah owner (pemilik hotel) yang telah menyetujui usulan anggaran dengan harapan mendapatkan keutungan yang besar dari hasil operasional hotel. Pihak ketiga adalah manajemen corporate, yang berkaitan dengan setoran berupa fee disamping itu juga meningkatkan nama besar manajemen corporate. Manajemen corporate akan mengevaluasi kinerja General Manajer (GM) yang ditempatkan sebagai pimpinan hotel tersebut dari pencapaian anggaran yang telah disepakati antara managemen corporate dan owner.

Anggaran yang diajukan GM akan disetujui oleh owner dan Managemen corporate jika sudah mencantumkan nilai nilai capaian yang diinginkan. GM dengan dasar anggaran bersama team manajer dan staf bekerja sama untuk mencapai target target sesuai anggaran. Untuk dapat mencapai target secara optimal GM beserta team membuat strategi strategi dan inovasi yang tepat untuk dapat memenangkan pasar perhotelan. Terciptanya capaian anggaran akan sangat berpengaruh terhadap ke semua unsur dalam lingkungan bisnis $h$ Urban Style by Front One Hotel.

\section{METODE PENELITIAN}

\section{Jenis penelitian}

Penelitian ini adalah penelitian kualitatif dengan melakukan studi kasus yang dilakukan pada Urban Style by Front One Hotel di Lampung, Sumatra Selatan. Yin (1996) menjelaskan bahwa studi kasus merupakan proses pencarian pengetahuan yang empiris guna menyelidiki dan meneliti berbagai fenomena dalam konteks kehidupan nyata. Tujuan dari penelitian studi kasus adalah menganalisa kasus menggunakan konsep teoritis, dan teori yang digunakan masih relevan dari unit atau bidang disiplin ilmu tertentu. Selain itu merekomendasikan tindakan yang bisa menjadi penyelesaian dari suatu kasus, atau bisa dikatakan peneliti bisa merekomendasikan solusi atas masalah yang menjadi penyebab suatu kasus.

\section{Responden}

Responden dalam penelitian ini adalah General Manager beserta Staf langsung di bawahnya. Dengan departemen Human Resource Development (HRD), Chief Accounting (CA), Sales Manager, Front Office Manager, House keeping (HK), Food and Baverage Manager (FBM) and Enginering Manager. Alasan pemilihan responden tersebut adalah mereka team yang terlibat dalam penyusunan anggaran yang akan diajukan untuk disetujui owner dan manajemen corporate. Dalam pelaksanaan anggaran team tersebut yang akan diminta konsekuensi dalam pencapaian target target yang disepakati bersama.

\section{Data}

Data yang digunakan adalah data primer dengan mengambil informasi dari dokumen pendukung yang diperlukan. Kuisioner yang dibagikan dan wawancara (menggunakan media zoom). Hasil wawancara diubah dalam bentuk transkrip sebagai sumber data. 


\section{Triangulasi}

Dalam penelitian kualitatif diperlukan suatu metode yang fungsinya untuk memeriksa dan menentukan tingkat validitas data dengan melakukan menganalisa dari berbagai perspektif dikenal dengan Triangulasi (Patton, 2001). Tujuan Triangulasi adalah agar mendapatkan konsistensi pada penelitian yang bermanfaat untuk mendapatkan kepastian bahwa data penelitian sudah sesuai atau valid. Validitas penelitian sangat penting untuk menghindari hasil penelitian yang tidak reliabel atau melibatkan unsur subjektifitas peneliti (Patton, 2001, dalam Ningrum, 2016).

Dalam penelitian ini menggunakan jenis triangulasi sumber data, yaitu dengan menggali kebenaran informasi tertentu melalui berbagai metode dan sumber perolehan data. Peneliti dalam mengumpulkan informasi selain melalui wawancara dan observasi, juga menggunakan observasi partisipan (participant obervation), dokumen tertulis, arsip, catatan resmi, catatan pribadi yang dianggap sebagai temuan serta gambar atau foto. Cara tersebut akan menghasilkan bukti atau data yang berbeda, yang akan memberikan pandangan yang berbeda pula mengenai permasalahan yang diteliti. Beragam pandangan itu akan menghasilkan kedalaman pemahaman untuk memperoleh pengetahuan.

\section{Variabel Penelitian}

Variabel kesiapan implementasi Beyond Budgeting, yaitu kebutuhan pada beyond budgeting, status organisasi, dan prasyarat keberhasilan implementasi.

Tabel 1. Skor Penilaian

\begin{tabular}{cc}
\hline Pilihan Jawaban & Skor Penilaian (bobot) \\
\hline Tidak Siap & 1 \\
Cukup Siap (Sedang) & 2 \\
Siap & 3 \\
\hline
\end{tabular}

Cara menghitung tingkatan skor (nilai) bobot dari kesiapan mengadaptasi beyond budgeting, dengan menentukan nilai interval data dan pengelompokan kategori, dengan rumus perhitungan sebagai berikut:

$$
\text { Interval }=\frac{\text { Skor }(\text { nilai }) \text { tertinggi }- \text { skor }(\text { nilai }) \text { terendah }}{\text { banyaknyatingkat skor }(\text { nilai })}
$$

Dalam penelitian ini skor (nilai) tertinggi dari interval kuesioner kesiapan implementasi beyond budgeting adalah 3 dan skor terendah adalah 1, serta banyaknya tingkat skor adalah 3. Sehingga setelah dimasukkan dalam rumus, nilai intervalnya:

$$
\frac{3-1}{3}=0,67
$$

Kesiapan adaptasi beyond budgeting dengan dasar dikategorikan berdasarkan nilai rata-rata sebagai berikut:

Tabel 2. Tingkatan Kesiapan Adaptasi Beyond Budgeting

\begin{tabular}{ccc}
\hline Skor Kesiapan & Kategori & Kesiapan \\
\hline $2,35-3,00$ & Hijau & Tinggi \\
$1,68-2,34$ & Orange & Sedang \\
$1,00-1,67$ & Merah & Rendah \\
\hline
\end{tabular}

Sumber: de Waal, 2005, dalam Ningrum 2016 
Kaharti

Kesiapan Adaptasi Metode Beyond Budgeting

Sebagai Upaya Pembaharuan Manajemen Kinerja

Tabel 3.Tabel Rekapitulasi Data Kuesioner

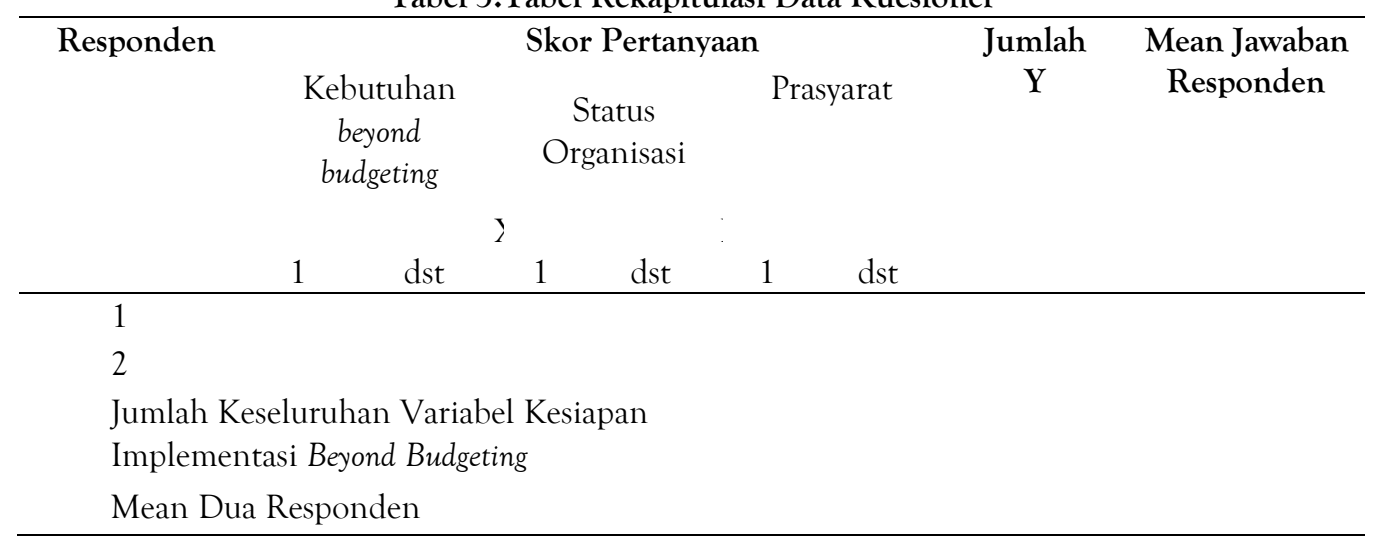

Keterangan:

$\mathrm{X} 1$ = Pertanyaan Pertama

$\mathrm{Y}=$ Variabel Kesiapan Implementasi Beyond Budgeting

Tabel 4. Kuisioner Kesiapan Beyond Budgeting (Adaptasi Andree A. de Waal 2005)

\begin{tabular}{|c|c|}
\hline No & Indikator Pengukuran Urban Style By Front One Hotel (USBFOH) \\
\hline A & Pertanyaan Pembuka (Kebutuhan BB) \\
\hline 1 & $\begin{array}{l}\text { Sebagai pelaksana anggaran perusahaan sudahkah Saudara merasa puas dengan proses } \\
\text { penganggaran di USBFOH? }\end{array}$ \\
\hline 2 & $\begin{array}{l}\text { Menurut Saudara apakah USBFOH siap untuk berganti mekanisme dalam proses } \\
\text { penganggaran? }\end{array}$ \\
\hline B & Pertanyaan Prinsip ( Status Organisasi) \\
\hline 1 & Bagaimana mekanisme sistem desentralisasi USBFOH saat ini? \\
\hline 2 & $\begin{array}{l}\text { Menurut Saudara mungkinkah USBFOH untuk melakukan proses desentralisasi dengan lebih } \\
\text { besar? }\end{array}$ \\
\hline 3 & Apakah manajemen dalam perusahaan untuk melaksanakan desentralisasi? \\
\hline 4 & Apakah manajer unit memiliki otorisasi dalam mengambil keputusan? \\
\hline 5 & Dapatkah manajer unit diberikan wewenang untuk bertindak? \\
\hline 6 & Apakah selama ini manajer senior di USBFOH siap untuk memeberikan delegasi wewenang? \\
\hline 7 & $\begin{array}{l}\text { Apakah di USBFOH menggunakan target dinamis dalam pencapaian anggaran? Disesuaikan } \\
\text { dengan kondisi pasar pada saat itu }\end{array}$ \\
\hline 8 & Apakah target yang dinamis sudah biasa diterapkan pada USBFOH? \\
\hline 9 & Apakah team pelaksana anggaran USBFOH siap untuk menerapkan target yang dinamis? \\
\hline 10 & Sampai saat ini, bagaimana lingkungan USBFOH memiliki perilaku customer oriented? \\
\hline 11 & Apakah di USBFOH memungkinkan untuk menciptakan sikap customer oriented? \\
\hline 12 & Apakah team manajemen USBFOH siap untuk mengimplementasikan sikap customer oriented? \\
\hline 13 & $\begin{array}{l}\text { Apakah gaya manajemen USBFOH dapat } \\
\text { dideskripsikan sebagai model pembinaan? }\end{array}$ \\
\hline 14 & Dapatkah USBFOH mengembangkan gaya manajemen sistem pembinaan? \\
\hline 15 & $\begin{array}{l}\text { Apakah team manajemen USBFOH siap untuk melakukan pengembangan gaya manajemen } \\
\text { model pembinaan? }\end{array}$ \\
\hline 16 & $\begin{array}{l}\text { Menurut Saudara apakah target di HUSBFOH bersifat relatif terhadap } \\
\text { persaingan? }\end{array}$ \\
\hline 17 & Mungkinkah USBFOH menerapkan sistem penetapan target relatif? \\
\hline 18 & Apakah tem manajemen USBFOH siap untuk melakukan penetapan target relatif? \\
\hline 19 & $\begin{array}{l}\text { Dalam hal pemilihan strategi di USBFOH menggunakan mekanisme dari bawah ke atas (bottom- } \\
\text { up)? }\end{array}$ \\
\hline 20 & $\begin{array}{l}\text { Mungkinkah di USBFOH menggunakan proses penetapan strategi berkelanjutan dari bawah ke } \\
\text { atas (bottom-up)? }\end{array}$ \\
\hline
\end{tabular}


21 Menurut Saudara apakah team manajemen USBFOH siap untuk melakukan proses penetapan strategi berkelanjutan dari bawah ke atas (bottom-up)?

22 Apakah USBFOH menggunakan sistem rolling forecasts yang dapat memeprediksi cash flows enam kuartal ke depan?

23 Mungkinkah USBFOH menerapkan rolling forecasts yang memprediksi cash flows enam kuartal ke depan?

24 Apakah team manajemen USBFOH siap memprediksi cash flows enam kuartal ke depan?

25 Bagaimana mekanisme penentuan alokasi sumber daya di USBFOH?

26 Apakah di USBFOH memungkinkan penerapan proses alokasi sumber daya fleksibel, dengan dasar rencana bisnis berkualitas baik?

27 Apakah team manajemen USBFOH siap untuk menetapkan sistem alokasi fleksibel?

28 Selama ini apakah USBFOH memiliki proses ketersediaan informasi manajemen yang efisien dan efektif, serta indikator keuangan dan non-keuangan?

29 Apakah USBFOH memeungkinkan melakukan perbaikan dalam memperbaiki proses ketersediaan informasi manajemen?

30 Apakah team manajemen $\mathrm{HUSBFOH}$ siap untuk melakukan perbaikan proses ketersediaan informasi manajemen?

31 Bagaimana USBFOH menetapkan sistem penghargaan (reward) yang berdasarkan gabungan penghargaan individu dan kelompok?

32 Apakah USBFOH memungkinkan menerapkan sistem penghargaan berdasarkan pada hasil individu dan kelompok?

33 Apakah team manajemen USBFOH siap untuk menerapkan sistem penghargaan berdasarkan pada hasil individu dan kelompok?

C Pertanyaan Akhir (Prasyarat)

1 Apakah USBFOH bagian dari perusahaan yang lebih besar atau group perusahaan?

2 Apakah USBFOH berwenang untuk adaptasi dan mengubah proses penganggaran?

HASIL DAN PEMBAHASAN

\begin{tabular}{cccc}
\hline No & Ukuran Kesiapan & Prinsip Beyond Budgeting $(\mathbf{B B})$ & Warna \\
\hline 1 & Kebutuhan BB & Persiapan adopsi BB & Hijau \\
2 & Struktur Organisasi & Kerangka kerja pemerintahan sendiri & Hijau \\
& & Manajer yang diberdayakan & Orange \\
& & Akuntabilitas untuk hasil yang dinamis & Merah \\
& & Organisasi jaringan & Orange \\
& & Koordinasi pasar & Orange \\
& & Gayajau \\
& & Tepemimpinan yang suportif & Orange \\
& Penetapan strategi berkelanjutan & Orange \\
& & Sistem antisipatif & Merah \\
& & Sumber daya sesuai kebutuhan & Merah \\
& & Informasi terdistribusi dengan cepat & Orange \\
& & Penghargaan tim relative & Orange \\
& & Otoritas mengadaptasi proses BB & Merah
\end{tabular}

Sumber: Data diolah (2021)

Permasalahan yang diuraikan dan ketidakpuasan terhadap proses penganggaran saat ini memotivasi manajemen Urban Style by Front One Hotel untuk mengisi kuisioner, untuk melihat apakah metode Beyond Budgeting dapat menjadi alternatif bagi perusahaan. Dalam 


\section{Kaharti}

Kesiapan Adaptasi Metode Beyond Budgeting

Sebagai Upaya Pembaharuan Manajemen Kinerja

penjelasan dibawah ini disajikan hasil transkrip wawancara dipilih jawaban dengan sumber yang kompeten terkait dengan relevansi penugasan.Meskipun seluruh team menjadi responden dalam penelitian ini. Uraian Penjelasan hasil adalah sebagai berikut:

1. Persiapan Penerapan Beyond Budgeting.

"Anggaran dibuat dengan memaksakan pencapaian target yang cukup sulit untuk komdisi yang tidak normal. Seperti dalam masa pandemic saat ini kondisi bisnis perhotelan sangat memprihatinkan. Tidak memungkinkan mencapai hasil sesuai target baik untuk penjualan kamar atau pun MICE (meeting, incentives, confetencing and exhibition). Mengetahui ada metode pengendalian selain anggaran (Beyond Budgeting) diharapkan dapat membuat perencanaan yang lebih dapat menyesuaikan dengan keadaan bisnis perhotelan" (Sumber: Sales Manager)

Kebutuhan Beyond Budgeting diperlukan disebabkan manjemen tidak puas dengan proses penganggaran saat ini dan melihat kebutuhan yang jelas untuk mengubah proses ini.

2. Prinsip 1: kerangka pemerintahan sendiri.

"Dalam pelaksanaan kegiatan operasional, manajemen hotel diberikan wewenang untuk melaksanakan penerintahan sendiri dalam arti pihak corporate dan owner memberikan keleluasaan dalam memilih cara untuk mencapai target yang ada dalam anggaran yang telah ditetapkan" (Sumber: GM)

Organisasi memiliki struktur terdesentralisasi dengan tim bisnis, yang berfungsi seperti unit yang mengelola sendiri dalam model Beyond Budgeting.

3. Prinsip 2: manajer yang diberdayakan.

"Di Urban Style by Front One Hotel, manajer unit diberikan wewenang untuk mengatur departemennnya masing masing setelah dilakukan koordinasi antar bagian. Tujuannya adalah untuk melancarkan pelaksanaan tugas dan kecepatan kerja team" (Sumber: GM)

Tim bisnis hanya sampai batas tertentu berwenang untuk membuat keputusan secara mandiri. Dalam keadaan yang menguntungkan, tanggung jawab didelegasikan kepada tim, tetapi dalam kondisi yang tidak menguntungkan, wewenang ini diambil kembali oleh tim manajemen senior.

4. Prinsip 3: akuntabilitas untuk hasil yang dinamis.

"Dalam pencapaian target dinamis masih bisa dilakukan dengan perhitungan rata rata setahun. Penilaian kinerja yang dilaporkan dalam periode bulanan dan rata rata tahunan yang dikjadikan evaluasi kinerja manajemen" (Sumber : Chief Accounting/CA)

Manajer bertanggung jawab untuk tetap mencapai target keuangan .

\section{Prinsip 4: Organisasi jaringan.}

Tim bisnis terdiri dari manajer dari berbagai disiplin ilmu (pemasaran, penjualan, logistik, keuangan), yang bekerja sama untuk memposisikan dan menjual produk di segmen pasar tertentu sebaik mungkin. Tim sangat berorientasi pasar dan berfokus pada pelanggan.

6. Prinsip 5: koordinasi pasar.

"Untuk menciptakaan koordinasi dengan keadaan pasar, seluruh lingkungan hotel diberikan pemahaman dan budaya customer oriented dalam hal ini focus pada pelayanan terbaik yang diberikan untuk tamu tamu hotel" (Sumber: HRD) 
7. Prinsip 6: kepemimpinan yang mendukung.

"Di Hotel Urban peran GM dalam melakukan pembinaan terhadap team manajemen sangat penting. Gaya kepemimpinan yang menyesuaikan terhadap karakter tugas yang melekat pada setiap karyawan. Didukung kompetensi dari masing masing karyawan untuk sungguh sungguh bekerja agar hasil dicapai secara optimal. Contoh melakukan meeting pagi untuk mengontrol pekerjaan dan hasil kerja yang telah dicapai. Ikut serta ke lapangan jika diperlukan untuk melihat kondisi lapangan dan mengatasi masalah jika ada kemungkinan munculnya hambatan" (Sumber: HRD)

Perusahaan Urban Style by Front One Hotel adalah organisasi non-hierarki yang datar di mana orang dapat mengungkapkan pendapat mereka, dan di mana tim manajemen mengelola organisasi dengan cara pembinaan.

8. Prinsip 7: Target relatif.

"Target yang telah ditetapkan harus dipatuhi bersama. Target relative tidak diberlakukan di perusahaan ini" (Sumber: CA)

Hotel Urban menggunakan target tetap dan absolut yang tidak berubah sepanjang tahun, meskipun kondisi pasar berubah.

9. Prinsip 8: Pengaturan strategi berkelanjutan.

"Strategi dalam pencapaian target selalu berubah mengikuti perkembangan lingkungan bisnis. Berorientasi untuk memenuhi selera dan kebutuhan pasar pada saat itu memerlukan ide ide kreatif yang diperoleh dari penggalian informasi dari bawahan ke atasan (bottom up). Misalnya mengadakan cooking class ,bazar jajanan, lomba bernyanyi,dukungan hotel untuk pengusaha UMKM daerah setempat. Kolaborasi dengan pengelola pendidikan tinggi untuk mensuport perkembangan bisnis usaha kecil."(Sumber: GM)

Proses penetapan strategi dilakukan dari bawah ke atas berdasarkan masukan dari tim bisnis. Strategi Urban Style by Front One Hotel keseluruhan setahun sekali ditinjau dan, jika perlu, disesuaikan. Di dalam tim bisnis, tinjauan strategi ini dilakukan beberapa kali dalam setahun.

10. Prinsip 9: Sistem antisipatif.

"Penggunaan rolling forecast dalam periode akuntansi dilakukan secara bulanan dan 3 bulanan untuk memudahkan pengendalian target target kerja yang telah ditetapkan" (Sumber: $C A$ )

Urban Style by Front One Hotel tidak menggunakan perkiraan bergulir. Ini menggunakan tiga prakiraan bulanan yang tidak melampaui akhir tahun. Mereka berfungsi untuk memberikan gambaran kepada manajemen apakah target tetap akan tercapai pada akhir tahun.

11. Prinsip 10: Sumber daya sesuai kebutuhan.

"Alokasi sumber daya telah diatur sedemikian rupa dalam anggaran diharapkan sesuai dengan kebutuhan dan perencanaan dengan dasar penetapan tahun sebelumnya. Alokasi yang telah ditetapkan bersifat tetap untuk dipatuhi bersama oleh seluruh pelaksana anggaran. Akan tetapi seringkali ditemui kesulitan jika alokasi ternyata meleset dengan nilai cukup besar dengan realisasi yang dibutuhkan" (Sumber : CA)

Semua sumber daya selama proses penganggaran dibagi di antara tim bisnis, berdasarkan rencana investasi. 


\section{Kaharti}

Kesiapan Adaptasi Metode Beyond Budgeting

Sebagai Upaya Pembaharuan Manajemen Kinerja

12. Prinsip 11: Informasi terdistribusi dengan cepat.

"Semua informasi yang bersifat keuangan dan non keuangan terdistribusi cukup baik dengan dukungan perangkat system informasi yang mendukung kecepatan dan ketepatan dalam pengambilan keputusan dari berbagai lini. Baik dari staf, manager unit, general manager hingga owner dan corporate." (Sumber: GM)

Informasi dalam Urban Style by Front One Hotel berasal dari beberapa sumber, beberapa di antaranya bersifat ambigu sehingga terkadang membuat informasi tersebut tidak dapat diandalkan. Akibatnya, informasi manajemen tidak tersedia untuk semua orang dalam organisasi.

13. Prinsip 12: penghargaan tim relatif.

"Sejauh ini penghargaan (reward) atas kinerja berbentuk servis diberikan berdasar kelompok kerja bukan berdasar kinerja individu. Hal ini telah diberlakukan dari awal perusahaan dikelola. Dan untuk saat ini penghargaan atas kerja kelompok dirasa paling tepat untuk Hotel Urban karena semua pihak memiliki peran penting dalam tercapainya kepuasan pelayanan kepada tamu dan pencapaian target anggaran" (Sumber: HRD)

Struktur penghargaan didasarkan pada penghargaan kelompok. Hanya jika Urban Style by Front One Hotel sebagai perusahaan mencapai targetnya, bonus dibayarkan kepada karyawan.

14. Prasyarat untuk implementasi yang sukses.

"Hotel Urban adalah bagian dari Corporate Manajemen Azana, dalam pelaksanaan kegiatan operasional hotel telah diatur sesuai dengan standar yang telah ditentukan. jadi tidak ada kemungkinan nyata untuk membuat perubahan dalam proses penetapan target tanpa izin sebelumnya dari pihak corporate."

"Jika pengaturan perubahan mengenai pengendalian manajemen tentu dilakukan dari corporate terlebih dahulu untuk kemudian disosialisasikan dan secara bertahap dapat dilakukan adaptasi hingga sampai pada penerapan metode dengan sempurna." (Sumber GM)

Terkait dengan teori keagenan beyond budgeting dapat mengendalikan perilaku agen yang telah bergeser dari biaya terperinci menjadi tindakan terperinci. Akan tetapi dimungkinkan juga jika perusahaan menggunakan anggaran dasar aktivitas, dalam hal ini Beyond Budgeting melangkah lebih jauh dalam berfokus pada pengendalian (Hansen et al, 2003).

Sedangkan dalam teori ketergantungan sumber daya ditunjukkan dalam hasil tudi sebelumnya bahwa, ketika anggaran dirubah dengan menggunakan system alokasi sumber daya yang bersifat dinamis, maka akan muncul pola interaksi serta ketergantungan sumber daya menjadi bergeser hal ini terjadi dalam konteks sistem pengendalian manajemen berbasis lebih luas (Stergren, 2010).

\section{KESIMPULAN}

Berdasarkan analisis data dan pembahasan maka dapat ditarik kesimpulan bahwa kebutuhan Beyond Budgeting untuk diterapkan pada Urban Style By Front One Hotel adalah tinggi yang ditunjukkan hasil warna hijau. Keinginan dari team manajemen untuk mengadaptasi alternative sistem pengendalian hotel selain anggaran, yang adaptif dengan perubahan lingkungan. Urban Style by Front One Hotel memiliki potensi kesiapan sedang dalam mengimplementasikan Beyond Budgeting. Hal ini dilihat dari warna warna yang 
merepresentasikan hasil dari 12 indikator. Warna terbanyak adalah orange sebanyak 8 indikator yang artinya kesiapan dalam mengadaptasi Beyond Budgeting adalah sedang. Terbanyak kedua adalah warna merah pada 3 indikator dan terakhir yaitu satu indicator berwarna hijau. Satu satunya yang siap dalam proses adaptasi Beyond Budgeting adalah Kepemimpinan. Gaya kepemimpinan dengan model pembinaan terhadap karyawan yang berdampak pada pengembangan kemampuan karyawan untuk bekerja dengan baik. Urban Style By Front One Hotel tidak memenuhi prasyarat dengan indicator warna merah, jadi adanya hambatan untuk mengadaptasi metode pengendalian baru (Beyond Budgeting) untuk beralih dari anggaran tradional disebabkan karena manajemen (agen) tidak memiliki otoritas untuk menentukan system pengelolaannya sendiri. Urban Style by Front One Hotel merupakan bagian dari suatu corporate yaitu Azana Management Hotel yang terikat dalam manajerial yang sama.

Penelitian ini memiliki beberapa keterbatasan. Pada penelitian ini hanya dilakukan pada satu perusahaan saja yaitu Urban Style by Front One Hotel dan melibatkan tim manajemen sebagai responden sehingga data yang diperoleh hanya terbatas. Penelitian dilakukan secara studi kasus pada satu perusahaan saja sehingga hasilnya tidak bisa di gunakan untuk generalisasi pada perusahaan dengan bidang usaha yang sama. Oleh karena itu, Bagi para peneliti selanjutnya, sebaiknya melakukan penelitian Beyond Budgeting secara comprehensive dari persiapan, penerapan hingga evaluasi sehingga mendapat hasil penelitian yang lebih lengkap. Selain itu, Bagi para peneliti selanjutnya dapat melakukan penelitian dengan responden yang mewakili sebuah populasi sehingga hasil penelitian dapat dimanfaatkan secara luas.

\section{DAFTAR PUSTAKA}

Andira dan Subroto B. (2003). Pengaruh Perilaku Kepemimpinan Transformasional dan Transaksional terhadap Kinerja Karyawan Lini Depan Perusahaan Jasa. Jurnal Universitas Sriwijaya.

Bastian, Indra. (2006). Akuntansi Sektor Publik: Suatu Pengantar. Jakarta: Erlangga.

Daum, Jurgen H. (2002). Beyond Budgeting: A Model for Performance Management and Controlling in the 21st Century?. Newsletter Controlling and Finance, July Issue.

de Waal, André A. (2005). Is your organisation ready for beyond budgeting? Measuring Business Excellence, Vol. 9 - Iss 2 pp. 56 - 67.

Hope, J., \& Fraser, R. (2003). Beyond Budgeting: How Managers Can Break Free from the Annual Performance Trap. Boston: Harvard Business School Press.

Hope, J., \& Fraser, R. (2003). New Ways of Setting Rewards: The Beyod Budgetng Model. The Regrets of University of California.

Jensen, M. C. (2002). Corporate budgeting is broken, let's fix it.

Johnson, Shane. (2005). Beyond Budgeting. University of Glamorgan, Paper 3.3.

Ningrum ( 2016), Kesiapan Implementasi Beyond Budgeting, Universitas Sanata Darma, Yogyakarta

Stergren, Stensaker (2010), Management Control without Budget: A Field Studi of Beyond Budgeting n Practice, NHH Norwegian School of Economics and Business Administration, Bergen, Norway, European Accounting Review, Vol. 20, No. 1, 149 - 181, 2011

Suryanto, Kurniati ( 2019), Tinjauan Perubahan Sistem Penganggaran berbasis Kinerja di Indonesia, JPP: Jurnal Administrasi Publik dan Pembangunan Volume 1 Nomor 2, Juli Desember 2019

Player,( 2003), Why Some Organization Go Beyond Budgeting, Published online in Wiley InterScience (www.interscience.wiley.com). DOI 10.1002/jcaf.10146 Wiley Periodicals, Inc

Pflaeging, Niels (2006). What is Beyond Budgeting. Beyond budgeting Round Table. Hampshire: UK. 
Sandalgaard, Niels, \& Bukh, Per Nikolaj. (2014). Beyond Budgeting and Change: A Case Study. Journal of Accounting \& Organizational Change, Vol. 10 - Iss 3, pp. 409 - 423. 